\title{
The new social work radicalism
}

\author{
Iain Ferguson University of the West of Scotland
}

On a cold January morning in 2017, a group of social workers, service users, claimants, psychologists, counselors and others gathered outside the annual meeting of the British Psychological Society (BPS) taking place that year in Liverpool. Those present represented a wide variety of grassroots organisations including the Social Work Action Network, Psychologists against Austerity and the Mental Health Resistance Network (SWAN). They were there to protest the BPS's involvement in the UK government's use of "psycho-compulsion" as a tool for getting people off benefits. Academics Lynn Freidli and Robert Steam have defined psycho-compulsion as:

the imposition of psychological explanations for unemployment, together with mandatory activities intended to modify beliefs, attitude, disposition or personality. (Friedli \& Steam, 2015)

In practice, psycho-compulsion usually means the use of positive psychology approaches to encourage an "improved" attitude to finding work. Failure to involve oneself in workfare schemes based on these approaches can lead to the claimant facing sanctions-the reduction, or even total withdrawal, of benefits for often quite long periods of time. The distress which this can cause is evident in the following comments by a respondent in Friedli and Steam's (2015) study:

I am shy and have difficulty speaking to people and I will not do play acting in front of a group of people I am very uncomfortable with [...] I was told I would be sanctioned if I didn't take part, so I said I would get up, but I am not speaking [...] After that, we had to fill out yet another "benefits of being assertive" sheet (p.43).
Social workers' involvement in protests against the effects of austerity, the policy of making the poor pay for bailing out the banks in 2008, is an increasingly common feature of the British political scene. But the growing political involvement of social workers is far from being confined to the $\mathrm{UK}$, nor is it confined to a single issue. Social workers, students and academics in Greece, Slovenia and Australia, as well as the UK, have made a significant contribution to raising the profile of, and providing material support to, the thousands of refugees crossing their borders seeking to escape, war, oppression and poverty. Social workers as far afield as Hong Kong and Turkey have been active in the struggles in their countries to preserve democratic rights. And social workers in Boston and other parts of the USA have been actively involved in the Black Lives Matters movement and in the opposition to the racist and sexist policies of Donald Trump.

It would be wrong to exaggerate either the impact of these activities or the numbers of workers actively involved: this is still very much a minority movement. Nevertheless, when one considers the radical voices and networks which have sprung up in so many countries across the globe over the last decade, from Brazil to Hong Kong, from Hungary to New Zealand, we are justified in speaking of a "new radicalism" in social work.

Why a new radicalism? Firstly, while the ideas of the radical social work movement which flourished in the UK, Canada, Australia and the USA during the 1970s never entirely disappeared, in truth radical social work, and progressive social work more generally, was an early casualty of the neoliberal era inaugurated by Margaret Thatcher and Ronald Reagan in the early
AOTEAROA

NEW ZEALAND SOCIAL WORK 29(2), 131-132.

CORRESPONDENCE TO: lain Ferguson iain.ferguson@uws.ac.uk 
1980s. Some of these ideas persisted within the academy in the shape of feminist social work and anti-racist practice, as well as in the notion of critical social work, but often in a much-diluted form.

Secondly, while drawing on the lessons and experiences of earlier radical social work movements, the new movement has emerged out of, and been shaped by, a very specific phenomenon, namely rising opposition to neoliberal capitalism and the way in which it has re-shaped the world in general and social work in particular. Thus, an early source of dissatisfaction, captured by Chris Jones in his seminal study of state social work in Britain at the turn of the millennium, was the universal imposition of care management approaches, to the detriment not only of community-based methods but to relationship-based work in general. One respondent identified what had changed in the following way:

Being a care manager is very different from being a social worker as I had always thought of it. Care management is all about budgets and paperwork and the financial implications for the authority, whereas social work is about people. That's the crucial difference. (Jones, 2001, p. 553)

That shift towards care management was one important element in the creation of what Harris has called "neoliberal social work," based on the three processes of managerialisation, privatization and consumerisation (Harris, 2014). No one could deny the extent to which these processes have transformed social work practice in many countries, in both the state and the voluntary or NGO sectors. But in two important respects they have also fuelled the emergence of the new mood of radicalism within social work.

Firstly, neoliberal social work challenges the very essence of social work as a valuebased, relationship-based profession. In its place it offers a technical occupation whose primary concerns are with rationing scarce services, controlling "troublesome families" and meeting government policy objectives ("what works"). Small wonder then that many social workers across the globe have responded to this shrunken, distorted model in the same way as social workers in Glasgow, Scotland in 2004 when they called a meeting to launch SWAN entitled "I didn't come into social work for this!"

Secondly, neoliberalism is a global project and a global ideology. If one outcome of globalisation has been the creation of the obscene levels of inequality which have contributed to the Brexit vote in Britain and the election of Trump in the USA, another has been to increase the opportunities to "globalise resistance," to make connections between social movement activists in different countries.

So, while the radical social work movement of the 1970s was largely confined to Englishspeaking countries, already the new movement feels much more international, linking social work activists from Boston to Tokyo and all points between. In building that movement, journals such as Aotearoa New Zealand Social Work and our own journal, Critical and Radical Social Work, can play an important role: in documenting social movements, highlighting radical practice and encouraging theoretical debate. It is in such practical grassroots activities and movements that the hope for, and the possibility of, a different kind of world-and a different kind of social work-lies.

\section{References}

Friedli, L., \& Steam, R. (2015). Positive affect as coercive strategy: Conditionality, activation and the role of psychology in UK government workfare programmes. Medical Humanities, 41(1), 40-47. Retrieved from http:// mh.bmj.com/content/41/1/40

Harris, J. (2014). (Against) neoliberal social work. Critical and Radical Social Work, 2(1), 7-22.

Jones, C. (2001). Voices from the front line: State social workers and New Labour. British Journal of Social Work, 31(4), 547-562. 